\title{
THE INFLUENCE OF INTERNATIONAL BRAND IMAGE TOWARD GUEST'S DECISION TO STAY AT THE FOUR STAR HOTEL IN LAMPUNG
}

\section{PENGARUH CITRA MERK INTERNASIONAL TERHADAP KEPUTUSAN MENGINAP DI HOTEL BINTANG EMPAT DI LAMPUNG}

1) Program Studi Hospitality Management, Sekolah Tinggi Pariwisata Bogor

2) Program Studi Hospitality Management, Sekolah Tinggi Pariwisata Bogor

Diterima 20 Mei 2021 /Disetujui 30 Mei 2021

\begin{abstract}
This survey research using the quantitative method was carried out during the Covid-19 pandemic, from May to August 2020 at the 4-star hotel in Lampung Province, Indonesia. The purpose of this research is to find out whether the independent variable, namely the image of the international hotel brand, has an effect on the dependent variable of the guest's decision to stay at the four-star hotel? Primary data of the study were obtained from the results of distributing questionnaires which were carried out directly to 60 guests who were staying, as research samples and measured using a Likert scale of 1 - 4. Apart from distributing questionnaires, research data collection was also gained through observation, documentation and literature review. All data collected were then grouped, reduced, tabulated and processed, analyzed descriptively and statistically, in accordance with the context of the problem being studied using the SPSS 22.0 software tool.

Based on the simple linear regression analysis technique $T$ test (partial), $R$ test and $R$ square test, it was found that the value of $T$ count $(9,048)$ was greater than the T table $(1,671)$, with a significance value of 0 or below the significance limit of 0.05. Both variables have a correlation coefficient of 0.765 and a coefficient of determination of 0.585. So it can be concluded that the international hotel brand image has a strong, positive and significant influence on guest decisions to stay at the 4-star hotel in Lampung, with an effect of 58.5\% while the rest, namely $41.5 \%$, is influenced by other variables not examined in this study.
\end{abstract}

Keywords: Brand Image, Purchase Decision, Simple Linear Regression, International Brand

\section{ABSTRAK}

Penelitian survey yang menggunakan metode kuantitatif ini dilakukan pada saat pandemi Covid-19 yaitu bulan Mei hingga Agustus 2020 di Hotel N Lampung. Tujuan penelitian untuk adalah untuk mengetahui apakah variabel independen yaitu citra merk hotel internasional berpengaruh terhadap variabel dependen keputusan tamu menginap di hotel berbintang empat tersebut? Data primer penelitian didapat dari hasil penyebaran kuesioner yang dilakukan secara langsung kepada 60 tamu yang sedang menginap, sebagai sampel penelitian dan diukur menggunakan skala likert 1 -4. Selain melalui penyebaran kuesioner, pengumpulan data penelitian juga diperoleh melalui observasi, dokumentasi dan kajian pustaka. Seluruh data yang terkumpul kemudian dilakukan pengelompokan, reduksi, tabulasi dan olah data, dianalisis secara deskriptif dan statistik, sesuai dengan konteks permasalahan yang diteliti menggunakan alat bantu software SPSS 22.0.

Berdasarkan hasil teknik analisis regresi linear sederhana, Uji T (partial) dan Uji R2, didapat nilai T Hitung (9,048) lebih besar dibanding T Tabel (1.671), dengan nilai signifikansi 0,0 atau di bawah batas signifikansi 0,05. Sehingga dapat disimpulkan bahwa citra merk hotel internasional berpengaruh signifikan terhadap keputusan tamu menginap di Hotel N Lampung, dengan pengaruhnya sebesar $76.5 \%$ sedangkan selebihnya yaitu 23,5\% dipengaruhi oleh variabel lain yang tidak diteliti dalam penelitian ini.

Kata Kunci : Citra Merk, Keputusan Pembelian, Regresi Linear Sederhana, Merk Internasional 


\section{Introduction}

Lampung, which is geographically located in the southern part of Sumatra Island, is one of the favorite tourist destinations and has huge potential for Indonesian tourism and the hotel industry. However, the high rate of hotel growth that exceeds the level of tourist visits coming to Lampung, creates increasingly fierce competition for hotel business managers. Supported by current advances in digital technology, hotel managers are competing in utilizing an online marketing system that offers various kinds of information, conveniences, choices and even promotional programs that are very attractive to consumers. The large number of accommodation options in Lampung is actually very beneficial for tourists because it provides many alternative choices. For the accommodation industry, of course, it will be increasingly challenging for them to try to attract consumers and compete for marketshare. This can be seen from the data where the occupancy rate of star-rated hotel rooms in Lampung only reaches an average of $48 \%$ to $70 \%$ per month. Figure 1 . shows the monthly average occupancy rate of star-hotel rooms, during 2017 to 2019 :

Figure 1. Room Occupancy Rate of Star-Hotels in Bandar Lampung

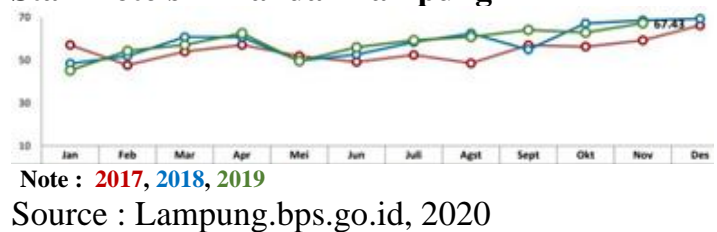

To determine the hotel selection to stay, a customer will usually carry out a process for making a purchase decision in advance. According to Sumarwan (2014: 377), a purchase decision is a consumer decision that will occur if the consumer's desire to buy an item is unanimous which includes what items to buy, whether to buy or not, when to buy, where to buy, how to pay for it, and etc. The decision to buy or not to buy is part of the elements inherent in each individual called behavior, which refers to tangible physical actions that can be seen and measured by others.

According to Kotler and Keller (2016: 195), in the process of a purchase decisison, there are several stages carried out by consumers, namely: problem recognition, information search, alternative assessment, purchase decisions, and post-purchase behavior. Many factors can influence consumers in deciding to buy, including: (1). Products, where the company must consider the value of a product, variety and quality of the product, (2). Distributors, where each buyer has different considerations in terms of determining a distributor due to factors of close location, low prices, product availability. (3). Purchase Time (4). Purchase Amount and (5). Brands, where buyers have to make decisions about which brands to buy, the trust and popularity of certain brands (Kotler \& Keller in Soeswoyo \& Tumbelaka, 2020).

According to Tjiptono (2014: 3), understanding brand image is crucial for marketers and brand owners. At least, there are several fundamental reasons that support brand image, since the brand is one of the most important strategic assets of any company that is able to create value or benefits for customers and the company, it can can be a measure of business performance success (long term survival), has a strategic role as a characteristic, the quality of the company that is able to suppress the perceived risk perception of consumers. Whitwell in Tjiptono (2014: 22) explains that understanding the role of brand strategy cannot be separated from the three supporting components of brand image, namely: (1). Corporate image is the audience's perception of the company's brand identity, (2). User image is a positive consumer image for a brand, and (3). Product Image is the perception of the product or service being offered.

The $\mathrm{N}$ Hotel is a 4-star hotel managed by an international hotel chain. Located in the center of Bandar Lampung City, the hotel has an ideal location because it can directly see the beach and mountain views, and is close to various famous tourist attractions in Bandar Lampung such as the water recreation park, Lembah Hijau, Lampung Museum and Mutun Beach. The hotel, which was founded in 2010, has a capacity of more than 200 rooms equipped with various attractive facilities such as a restaurant, meeting rooms, swimming pool, sauna, Jacuzzi, spa and gym. This hotel is one of the some star- hotels in Lampung, which were still operating at the time of the Covid-19 pandemic which had a severe impact on the tourism and hospitality industry in Indonesia and even in almost all parts of the world. When the spread of Covid-19 in Indonesia began to 
be identified in March 2020, the hotel industry suffered huge losses, even many star hotels temporarily closed their operational activities for 3-4 months since April 2020. What made the N Hotel Lampung still maintain its daily operational even during the Covid-19 pandemic? What makes customers still interested in staying at the hotel? Some of these questions still need further study.

Table 1. shows some comments and recommendations for the $\mathrm{N}$ hotel customers through the Online Travel Agent (OTA) application, which are quite interesting to observe:

Tabel 1. The Hotel Guests Review

\begin{tabular}{ll} 
Date & GuestReview \\
\hline I have to meet some people \\
in lampung for my business \\
and I was stay in great \\
hotel with good service
\end{tabular}

Source :https://www.agoda.com/id-id/novotel-lampunghotel/reviews/bandar-lampung-id.html?

The result of some academics researches state that especially during the Covid-19 pandemic, there is a market tendency that prefer to stay at hotel that have a good reputation because they are believed to have good management systems and standards (Ranasinghe \& Damunupola, et al., 2020).

Another study conducted by Ciftci \& Berezina et al. (2020), proving that hotel / accommodation booking decisions are influenced by images based on trust in recommendations or comments on online reviews. Several previous studies conducted by Iskandar (2020), Permana (2016), and research by Lingga, R.U (2016), show that there is an

influence of Brand Image toward Purchasing Decisions.

Based on these data and phenomena, the authors are interested in making a study to find out more about the influence of the international brand image on consumer decisions to stay at the $\mathrm{N}$ Hotel, especially during the Covid-19 pandemic. The results of this study are expected to become a reference for further research, and can provide input to the industry as a basis for strategic decision making.

Reffer to the study of several theories as well as the result of previous researches, and the conceptual framework of this research which is described systematically in figure 2 , the hypotheses in this study is :

Ho : International Brand Image doesn't influence consumer decisons to stay at The $\mathrm{N}$ Hotel.

$\mathrm{Ha}$ : International Brand Image influences consumer decisions to stay at The N Hotel.

Figure 2. Conceptual Framework

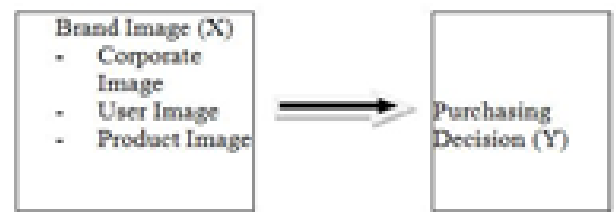

Source : Whitwell quoted by

Tjiptono(2014) and Kotler \& Keller quoted by Soeswoyo \& Tumbelaka (2020)

\section{Research Method}

This research was conducted from May to August 2020, with a locus at the N Hotel Lampung. The method is carried out quantitatively using data that is assessed 
(scoring). Data collection technique was carried out through direct survey based on observation and memory. The researchers made a direct visit to the hotel as object of research, in order to obtain the necessary information. Some essential information was obtained by observing, remembering and recording direct information from one of the hotel managers. Other secondary research data, obtained from company documentations and research journals. Primary data obtained from the results of distributing questionnaires to collect answers from respondents through a list of structured and closed statements, in writing. This study used a Likert Scale to measure the opinions and perceptions of a person or group of people about social phenomena (Sugiyono, 2016). The modification of four scales was used because it is considered to have the advantage of being able to capture research data more accurately because the undeciden answer category (neutral/undecided) which has multiple meanings is not used in the questionnaire (Hadi, 1991: 19). With the Likert scale, the measured variables are translated into variable indicators, then these indicators are used as a starting point for compiling instrument items in the form of statements that are favorable (positive) or unfavorable (negative). The use of the Likert scale also makes it easy for respondents to answer and makes it easier for researchers to process data. The distribution of questionnaires was carried out to guests staying at the N Hotel Lampung and entrusted to them through the receptionist and hotel manager. The sample collection technique is carried out in a conventional manner, that is, it is distributed to several guests who are easy to find, and they are comfortable cooperating with them to fill it out. In a pandemic condition due to Covid-19 where there are not too many hotel guests, a questionnaire was distributed during MayJune 2020, resulting in sixty (60) respondents according to certain criteria as data sources, which were then determined as the research sample. The theoretical basis used to determine the number of sampling used in this study is according to Roscoe quoted by Uma Sekaran (2013: 295), which states that sample sizes of more than 30 and less than 500 are appropriate for most studies.

The data obtained were then analyzed descriptively and quantitatively to determine the value of the independent variable and the dependent variable. The independent variable in this study is the image of the international hotel brand, while the dependent variable is the decision to stay at the $\mathrm{N}$ Hotel. The primary and secondary data that the author has collected are processed using the Statistical Package for Social Science (SPSS) software calculation tool version 22 .

\section{Data analysis technique}

To test the questionnaire as a research instrument, the validity and reliability tests were carried out. The technique used to test the validity is the Pearson moment product correlation technique. Testing using the SPSS program was carried out by correlating each statement in the total score. The correlation value (r) is compared with the critical number in the correlation table, to test this correlation coefficient a significant level of $5 \%$ is used, and if $r$ count $>r$ table then the statement is valid (Hair at al., 2009). Reliability test is to measure indicators of variables. A questionnaire can be said to be reliable if the answers to the statements produce consistent or stable answers over time. The measurement of reliability in this study was done by using one shot (once measurement only). Result are made by measuring the correlation between the answers to the questions. A variable is said to be reliable if the Cronbach Alpha value is > 0.60 (Sugiyono, 2011). Before conducting the research Hypothesis Test, it is necessary to carry out the classical assumption test as a prerequisite for regression, called the Linearity, Normality and Heteroskedasticity Test.

Hypothesis testing is carried out using the simple linear regression analysis technique $\mathrm{T}$ test (partial), then the correlation coefficient and determinant coefficient tests are carried out to clarify the relationship and influence of the two variables. Simple linear regression analysis is a statistical method that functions to test the extent of the causal relationship between the Causal Factor Variable (X) and the Consequential Variable.

$\mathrm{T}$ test - Statistics are used to test the independent variables partially against the dependent variable. This test is done by comparing the value of $\mathrm{T}$ count and $\mathrm{T}$ table. If $\mathrm{T}$ count $>\mathrm{T}$ table with significance below $0.05(5 \%)$ then individually the independent variable has a significant effect on the dependent variable.

The Correlation Coefficient $(\mathrm{R})$ test is one of the inferential statistics that tests whether two 
or more existing variables have a relationship or not. If there is a relationship, we will look for how strong the relationship is. The nature of the correlation will determine the direction of the correlation (Wiratna Sujarweni, 2014). The coefficient of determination (R2) is a tool to measure how far the model's ability to explain variations in the dependent variable (Ghozali, 2012: 17).

\section{Results And Discussion}

Based on the results of data collected from 60 respondents who were guests staying at the Hotel, it is known that an overview of the respondents characteristics based on gender, age, education, and occupation are described in Table 2.

Table 2. Characteristics of Respondents

\begin{tabular}{ccc}
\hline Gender & $\mathbf{N}$ & $\mathbf{\%}$ \\
\hline Man & 45 & 75 \\
\hline Woman & 15 & 25 \\
\hline Age & $\mathbf{N}$ & $\mathbf{\%}$ \\
\hline 15-20 Tahun & 2 & 3 \\
\hline 21-30 Tahun & 14 & 23 \\
\hline 31-39 Tahun & 10 & 17 \\
\hline 40-41> Tahun & 34 & 57 \\
\hline Education & & \\
\hline SMA & 10 & 17 \\
\hline Diploma & 20 & 33 \\
\hline Sarjana & 23 & 38 \\
\hline Lainnya & 7 & 12 \\
\hline Occupation & & \\
\hline Students & 10 & 17 \\
\hline Eployees & 18 & 30 \\
\hline Entrepreneur & 21 & 35 \\
\hline Lainnya & 11 & 18 \\
\hline & &
\end{tabular}

Descriptive statistics are used to analyze the data that has been collected and aims to provide an overview of the data in terms of the mean, standard deviation, minimum and maximum values. Descriptive results for each indicator in the Brand Image variable can be seen in Table 3.

Table 3. Value Indicator of Brand Image

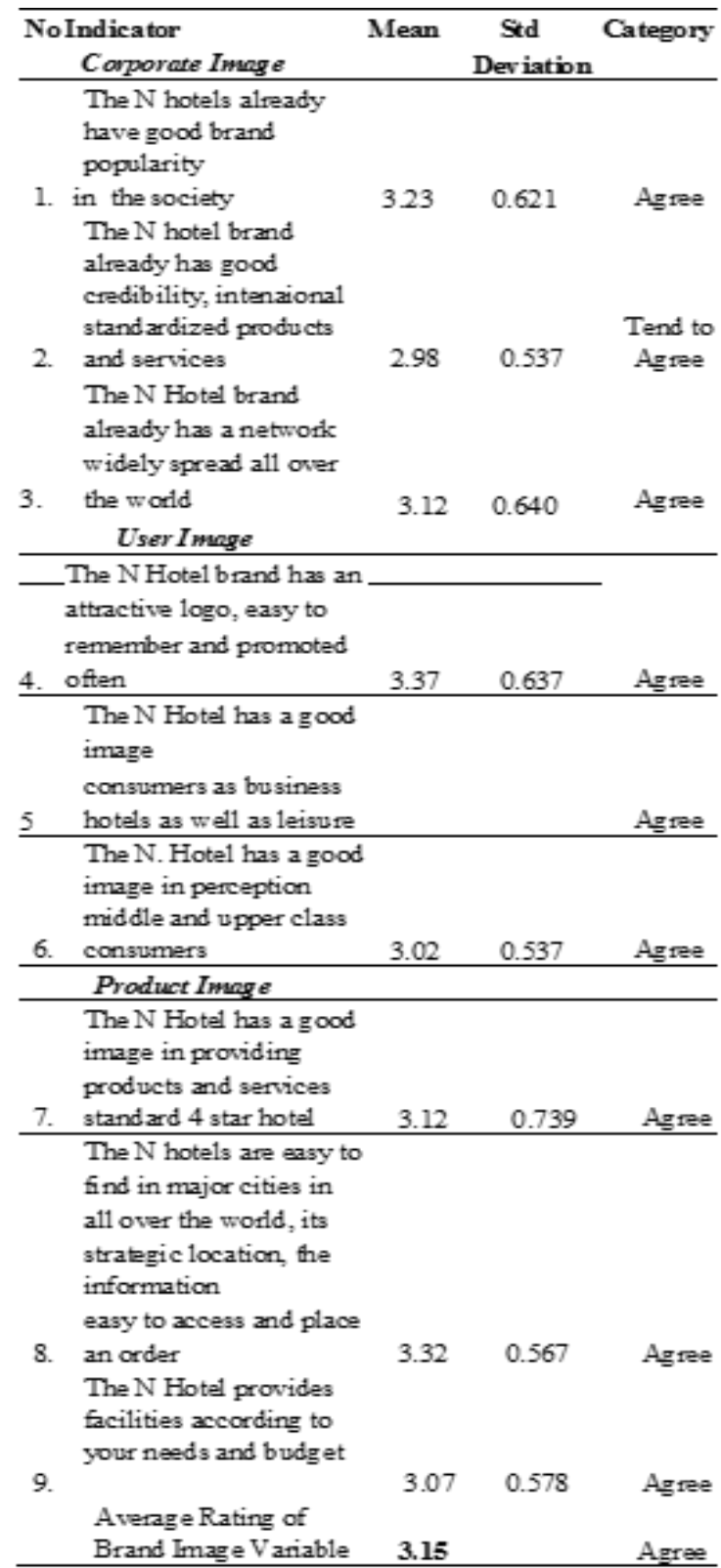

Based on Table 3. data, the mean score of the respondents' answers to the brand image variable is 3.15 or included in the agreed value category. The highest mean score is found in the item number 8 for the Product Image indicator with a mean score of 3.32, namely Agree that the brand hotel are easy to be found in big cities around the world, strategic location, easy access on information and reservations made. While the lowest indicator is in statement item number 2 with a mean score of 2.91, namely Tend to Agree that the hotel already has product credibility and international hotel service standards. The description of the indicator value in the Purchase or Stay Decision variable can be seen in Table 5 . 
Table 4. Value Indicator of Purchase Decision

\begin{tabular}{|c|c|c|c|c|}
\hline \multicolumn{2}{|c|}{ No Indicator } & Mean & Std & Category \\
\hline & & \multicolumn{3}{|c|}{ Deviation } \\
\hline 11 & $\begin{array}{l}\text { The decision to stay at the } \mathrm{N} \text { Hotel } \\
\text { because it has an image of complete } \\
\text { facilities with good quality }\end{array}$ & 3.23 & 0.621 & Agree \\
\hline 12 & $\begin{array}{l}\text { The decision to stay at the N Hotel, } \\
\text { because sure of the standard image of } \\
\text { a hotel chain brand international }\end{array}$ & 2.98 & 0.537 & $\begin{array}{l}\text { Tend to } \\
\text { Agree }\end{array}$ \\
\hline 13 & $\begin{array}{l}\text { The decision to stay at the N. Hotel } \\
\text { was made because the image of the } \\
\text { customers was seen from the } \\
\text { recommendations, reviews and } \\
\text { comments of guests who had stayed at } \\
\text { the hotel. }\end{array}$ & 3.12 & 0.640 & Agree \\
\hline & Average Value of Purchasing & & & \\
\hline & Decision Variable & 3.11 & & Agree \\
\hline
\end{tabular}

Based on table 4 data, the mean score of respondents' answers to the purchasing decision variable is 3.11 which is included in the Agree category. The highest mean score is in the statement of item number 11 with a score of 3.23, namely Agree that the decision to stay at the hotel is due to the image of having complete and good quality facilities. While the lowest indicator is indicator number 12 with a mean score of 2.9 , namely Tend to Agree on the statement of the decision to stay at the hotel because they believe in the standard image of the international hotel chain brand.

The research instrument was carried out by using the validity and reliability test. The results of the validity test were shown that the value of $R$ count $>R$ table at a significant level of 5\%. All indicator items in the Brand Image variable consisting of the dimensions of corporate image, user image and product image as well as all indicators in the purchasing decision variable are valid, as indicated by the value of Corrected ItemTotal Correlation ( $\mathrm{R}$ count) has a positive coefficient value and is greater than $\mathrm{R}$ Table (0.330).

Reliability test results are determined from the Cronbach Alpha value for each research variable. Based on the results of the reliability test, it is known that all variables have a Cronbach Alpha coefficient greater than 0.600 , so that the instrument is declared reliable and suitable to be used.

The regression prerequisite was carried out by using the Linearity, Normality and Heteroscedasticity Test. The result of the prerequisite regression test is that all the data are proven Linear, Normal and Homogeneous, so that then a Hypothesis Test can be performed.

\section{Research Hypothesis Testing}

\section{T- test (partial)}

This T- test shows the partial influence of the independent variables on the dependent variable. The independent variable of this research is Brand Image with indicators of company image, user image and product image, while the dependent variable is Consumer Purchasing Decision. To draw conclusions, it is done by comparing T-count with T-table with the criteria $\mathrm{Ha}$ accepted if T-count $>$ T-table. Significant regression criteria if the Sig is less than $0.05(<0.05)$. The results of the research T-test can be seen in the table 5 :

Table 5. T-test (Partial)

\begin{tabular}{|c|c|c|c|c|c|}
\hline & Unstan & ndardized & Standardized & & \\
\hline & $\begin{array}{l}\text { Coefic } \\
\text { ents }\end{array}$ & & Coefficients & & \\
\hline Model & $\mathrm{B}$ & Std. Error & Beta & $\mathrm{t}$ & Sig. \\
\hline (Constant) & .730 & .955 & & .765 & .448 \\
\hline \multicolumn{6}{|l|}{$\begin{array}{l}\text { Brand Image } \\
(\mathrm{X})\end{array}$} \\
\hline & .303 & .034 & .765 & 9.048 & .000 \\
\hline
\end{tabular}

T-count result of the Brand Image is 9,048, and the $\mathrm{T}$ table value with df 58 and $5 \%$ degree of error obtained 1,671, so that the value of $\mathrm{T}$ count $(9.048)>$ T-table value (1.671). Based on the $\mathrm{T}$ count value, the hypothesis $\mathrm{Ho}$ is rejected, its mean that hypothesis $\mathrm{Ha}$ is accepted. The results obtained significance value 0.00 or less than $0.05(0.00<0.05)$, so it can be said that the International Brand Image independent variable has a significant effect on the Consumer Purchase Decision variable to stay at the hotel.

The results of this study are in line with the results of research conducted by Iskandar (2020), Permana (2016), and study by Lingga, R.U (2016) which prove the influence of Brand Image on Purchasing Decisions. The results of this study also support the results of research on the behavior of purchasing decisions or staying at hotels during the Covid-19 pandemic conducted by Ranasinghe \& Damunupola, et al. (2020) and Ciftci \& Berezina et al. (2020). 


\section{Correlation Coefficient Test and Coefficient of Determination}

The result of the $\mathrm{R}$ value (Correlation Coefficient) in Table 6 is positive 0.765 , this shows that there is a positive relationship between the Brand Image independent variable and the Consumer Purchase Decision dependent variable, and it is said to be strong because it is close to the value 1. Meanwhile, to determine the influence of the variable independent of the dependent variable seen from the value of the $\mathrm{R}$ square coefficient (coefficient of determination) obtained is 0.585. This means that the Brand Image independent variable has a contribution of $58.5 \%$ to the dependent variable, namely Consumer Purchase Decisions (Y). Meanwhile, the remaining $41.5 \%$ was influenced by other variables which were not examined in this study.

Table 6. Correlation Coeficient and Determination Correlation

\begin{tabular}{|c|c|c|c|c|}
\hline & & & $\begin{array}{c}\text { Adjusted } \\
\text { R }\end{array}$ & $\begin{array}{l}\text { Std. Error } \\
\text { of }\end{array}$ \\
\hline \multicolumn{5}{|c|}{$\mathrm{R}$} \\
\hline Model & $\mathrm{R}$ & Square & Square & the Estimate \\
\hline 1 & $.765^{\mathrm{a}}$ & .585 & .578 & .714 \\
\hline
\end{tabular}

\section{Conclusion \& Implications}

Based on the results of data analysis and hypothesis testing that have been done, the results of the research are as follows: The results of hypothesis testing are obtained by using the results of the T-test where the $\mathrm{T}$ Count is calculated $(9,048)>$ T-table value $(1,671)$ so that the Ha hypothesis that the influence of Brand Image has an influence on Consumer Purchasing Decisions to stay at the $\mathrm{N}$ Hotel can be declared acceptable. The significance level of the influence between the variables shows a result of 0.000 which is smaller than 0.05, so it is said that the Brand Image variable has a significant level of influence on Purchasing Decisions to stay at the $\mathrm{N}$ Hotel Lampung. The result of correlation coefficient value is $\mathrm{r}=0.765$, which means positive and strong. The magnitude of the influence of $\mathrm{X}$ on $\mathrm{Y}$ can be seen from the results of the coefficient of determination which is $58.5 \%$. In general, it can be concluded that the Consumer Purchase Decision is influenced positively, strongly and significantly by the Brand Image of $58.5 \%$, while the remaining $41.5 \%$ is influenced by other variables not examined in this study.

\section{Implications}

Based on the results of data analysis, suggestions and implications that can be applied are as follows: For further research, it can be added other variables that affect purchasing decisions such as the marketing mix or use other methods such as the mix method. The operational implications that can be applied in the industry are: Maintaining service and operational standards, by conducting strict and regular supervision of daily operational activities, selective selection of employees in accordance with policies and procedures determined by the management group.

With regard to the lowest indicator in variable Y (Purchase Decision), management must maintain and improve services according to internaional group standards, be able to carry out various service innovations by raising local wisdom in Lampung Province, and make improvements to several facilities according to standards.

\section{References}

Cifti. O, Berezina. K, Cavusoglo, Cobanoglu.C, Winning. (2020). The Battle : The Importance of Price and Online Reviews for Hotel Selection, Advances in Hospitality and Tourism Research (AHTR), An International Journal of Akdeniz University Tourism Faculty, Webpage: http://www.ahtrjournal.org/, Vol 8(1), 177-202. Doi 10.30519/ahtr 528150

Hadi, Sutrisno. (1991). Statistik dalam Basica Yogyakarta : Andi

Hair, Joseph F., et al. (2009). Multivariate Data Analysis: A Global Perspective. 7th ed. Upper Saddle River: Prentice Hall

Iskandar, Hari . (2020). Analysis The Effect Of Brand Image Towards Customer Decision Staying At Hotel X.. Jurnal Hospitality dan Pariwisata .6 (2): 56- 
105.

https://journal.ubm.ac.id/index.php/ hospitality-pariwisata. DOI : dx.doi.org/10.30813/.v6i2.

Kotler, Philip. \& Gary Armstrong. (2014). Principle Of Marketing, 15th edition. New Jersey: Pearson Prentice Hall.

Kotler, Philip \& Keller. Kevin L. (2016). Marketing Management, $15^{\text {th }}$ Edition, Pearson: Education, Inc.

Lingga, R. U. (2016). Pengaruh Brand Image Terhadap Keputusan Konsumen Menggunakan Hotel Amaris Di Samarinda, eJournal Ilmu Administrasi Bisnis, 4 (2)

Permana, S. Indra. (2016). Pengaruh Kualitas Produk dan Brand Ambassador Terhadap Citra Merek Serta Dampaknya Terhadap Keputusan Pembelian Pada Distro Relic Syndicate.Skripsi. Universitas Pasundan, Bandung

Ranasinghe, R., Damunupola, A., Wijesundara, S., Karunarathna, C., Nawarathna, D. and Gamage, S., Ranaweera, A. and Idroos, Ali A.(2020). Tourism after Corona: Impacts of Covid 19 Pandemic and Way Forward for Tourism, Hotel and Mice Industry in Sri Lanka. Uva Wellassa University, Sri Lanka. SSRN: https://ssrn.com/abstract=3587170 or http://dx.doi.org/10.2139/ssrn.358 7170

Guest

Reviews. (2020). www.Agoda.com/idid/Novotel-lampunghotel/reviews

Sekaran, Uma. (2013). Metodologi Penelitian Untuk Bisnis. Jakarta: Salemba empat

Soeswoyo, D.M. \& Tumbelaka, D. (2020). Dampak Promosi Digital Line terhadap Keputusan Pembelian Pelanggan Dunkin Donuts. Jurnal Fame, 3(1). Hal 1-12. Universitas Bunda Mulia Jakarta

Sugiyono. (2016). Metode Penelitian Kuantitatif, Kualitatif dan $R \& D$. Bandung : Alfa Beta

Sugiyono. (2011). Statistika untuk Penelitian. Bandung : Alfa Beta

Tjiptono, Fandy. (2014). Branding \& Brand Longevity. Yogyakarta. Andi.

Tingkat Hunian Kamar Hotel Berbintang di Bandar Lampung, melalui https://lampung.bps.go.id/pressrelea se/2019/02/01/606/tingkatpenghunian-kamar/ Diakses pada 27 Maret 2020

Tingkat Perkembangan TPK Hotel Berbintang di Bandar Lampung, melalui https://lampung.bps.go.id/pressrelea se/2019/10/01/730/ Diakses pada 27 Maret 2020 